\title{
CUSTOMS AND TRADITIONS OF THE PEOPLES OF DAGESTAN AS THE BASIS OF THE DAGESTAN MENTALITY
}

\author{
(C) Maida G. Mustafaeva, Sarat G. Hiyasova, Elmira Sh. Musaeva
}

\author{
Dagestan State Pedagogical University, Makhachkala, Republic of Dagestan, \\ Russian Federation \\ science-almanac@mail.ru
}

The features of the Dagestan mentality are studied, the characteristic of the traditional system of customary law embodied in adats and Sharia is given, the conclusion about their direct influence on the formation of the mentality of the Dagestan peoples is made. A number of customs and traditions of the peoples of Dagestan are analyzed, including such public institutions as hospitality, kunachestvo (friendship), twinning, atalychestvo (fosterage) and others, which embodied the identity, national psychology and mentality of the highlanders. The creative, humanistic beginning of the traditional national culture of Dagestan is justified and its key role in consolidating the peoples of Dagestan and strengthening good neighborhood relations with the peoples of the North Caucasus is emphasized. Analysis of the origins of traditional Dagestan culture allows us to better understand and accept the features of the modern Dagestan mentality, its specificity and uniqueness.

Key words: traditions, customs, adats, Sharia, Dagestan, mentality, namus.

[М.Г. Мустафаева, С.Г. Хиясова, Э.Ш. Мусаева Обычаи и традиции народов Дагестана как основа дагестанского менталитета]

Исследуются особенности дагестанского менталитета, дается характеристика традиционной системы обычного права, воплотившейся в адатах и шариате, делается вывод об их прямом влиянии на формирование менталитета народов Дагестана. Анализируется целый ряд обычаев и традиций народов Дагестана, в том числе такие общественные институты, как гостеприимство, куначество, побратимство, аталычество и другие, воплотившие в себе самобытность, национальную психологию и менталитет горцев. Обосновывается созидательное, гуманистическое начало традиционной национальной культуры Дагестана и подчеркивается ее ключевая роль в консолидации народов Дагестана и укреплении добрососедских отношений с народами Северного Кавказа. Анализ истоков традиционной дагестанской культуры позволяет лучше понять и принять особенности современного дагестанского менталитета. его специфику и уникальность.

Ключевые слова: традиции, обычаи, адаты, шариат, Дагестан, менталитет, намус.

Maida G. Mustafaeva - Ph.D. (Advanced Doctorate) in Philosophy, Professor, Dagestan State Pedagogical University, Makhachkala, Republic of Dagestan, Russian Federation.

Sarat G. Hiyasova - Ph.D. in Pedagogy, Associate Professor, Dagestan State Pedagogical University, Makhachkala, Republic of Dagestan, Russian Federation.

Elmira Sh. Musaeva - Ph.D. in Philosophy, Associate Professor, Dagestan State Pedagogical University, Makhachkala, Republic of Dagestan, Russian Federation.

Мустафаева Маида Ганифаевна - доктор философрских наук, профрессор, Дагестанский государственный педагогический университет, г. Махачкала, Республика Дагестан, Российская Федерация.

Хиясова Сарат Гасановна - кандидат педагогических наук, доцент, Дагестанский государственный педагогический университет, г. Махачкала, Республика Дагестан, Российская Федерация.

Мусаева Эльмира Шекералиевна - кандидат фрилософских наук, доцент, Дагестанский государственный педагогический университет, г. Махачкала, Республика Дагестан, Российская Федерация. 
For many centuries, peoples of Dagestan have developed a thoughtful system of legal and moral standards to establish a normal life in their auls, as well as to determine their attitude to neighbors, representatives of other peoples. These norms are called "adats" (in science they are called customary law). In everyday life, they had the power of law and represented a huge moral potential, uniting and consolidating all the peoples living in Dagestan into a single fraternal family.

Each aul had the customs representing the local legal and moral code based on rationality and respect for elementary justice in the solution of any given questions defining strict ethical and legal standards of the relations both between persons, and between the personality and society. For many centuries they existed orally and were passed down from generation to generation. But with the arrival of Islam and the Arabic language, as a carrier of a religious idea, with the help of the Arabic alphabet, some of adats were written on paper. As the Russian scientist M.M. Kovalevsky noted, "the literature of the late 18th and early 19th centuries is especially rich in notes and systematic descriptions of the highlanders' life" [5, p. 344].

From the middle of the 19th century, after the end of the Caucasian War, at the initiative of the tsarist administration, the official recording of adats and their translation into Russian began. In the "Collections of information about the Caucasian highlanders," published in the 60s in Tbilisi by the Caucasian Mountain Administration, five collections of adats were published: Kazikumukh, Darginsky, Kurinsky, Kaitago-Tabasaran and Samur districts. Soon, prominent Russian historians, culturologists, jurists and ethnographers who created fundamental works in this area joined this noble activity.

In 1882, R.I. Leontovich in Odessa published a two-volume book "Adats of the Caucasian highlanders. Material on customary law of the North and East Caucasus," in which all adats of the Caucasian highlanders, especially Dagestan, are investigated. His example was followed by M. Kovalevsky, I. Berezin, A. Berge, P. Butkov, A. Bekker, A. Zisserman, E. Kozubsky, A. Lavrov, N. Lvov, A. Omarov, D. Shikhaliev, P. Przhetslavsky, G. Chursin, V. Shvetsov and others.

"In almost every aul, in every rural community there are adats, the scientist A. Dirr wrote in the article "On customary law of Caucasian highlanders," which differ from adats of neighbors, but only on secondary issues, for example, the size of the fine, the number of witnesses and jurors, etc. Customary law determines the following everywhere: murder can be paid for by revenge or reconciliation on known conditions; hacking or theft, if the offender is captured at the scene of the crime, can also be settled without punishment; at the same time, adultery by the wife and lecherousness by the closest relatives through female lineage are punished by death. Injuries are treated at the expense of those by whom they were made; a caught thief returns stolen things" [1, p. 114].

The adat or customary court, being a concentrated expression of the wisdom of the people, was held by the Aqsaqals (elders) in accordance with established standards in order to maintain the order in the aul, combat crime, and resolve sports issues that arose between the villagers. The verdict of the court was handed down by special persons, each of whom was usually chosen by a majority vote.

The length of service in the adat court was usually at least a year, although there were cases of their monthly re-election. For their work, they received part of the money earned from the fine and had some benefits. The court verdict was delivered in the street, in the square, in front of the mosque, and in inclement weather in the house specially designated for this. The members of the adat court met every morning, listened to witnesses and accused, decided the cases by a majority vote, the verdict was delivered immediately, and measures to enforce it were taken immediately. Despite the difference in secondary issues, the Dagestan adats as a whole embodied the identity, national dignity and mountainous character of the entire Dagestan society. If we look deep into their sphere, we will 
come to the conclusion: they contain a generalized, time-tested centuries-old experience of the life of the highlanders of Dagestan [7].

At all times, from primitive to present days, the Dagestan highlanders have been living not only according to their traditions and customs, but also thanks to the coherence and wisdom of peoples who recognized the equality of all peoples of their region without exception. These fraternal coherence and mutual respect were carried by our citizens through the entire history of their development.

This is described in detail by many books of our predecessors, among which a special place belongs to the monograph by G.F. Chursin "Essays on the Ethnology of the Caucasus," published in Tbilisi in 1913, as well as the scientific works of scientists of the Dagestan branch of the Academy of Sciences of Russia, Dagestan State University, other universities and scientific institutions of the republic. "From beneath of the peculiar cover of folk customs and beliefs," G.F. Chursin wrote in his book, "in the light of scientific research, bright pictures of the past of human culture are opened up to us. In these monuments, as if again, a centuries-old life path passes before us. This gives great importance and poetic attractiveness to the scientific study of folk customs and views" [5]. "The closest acquaintance with the life of the Caucasian peoples, the author wrote, "opens up to the researcher an unobservable wealth of ethno-graphic facts, the development of which, undoubtedly, can shed a lot of light on questions from the history of primitive culture, in particular from religious views. A lot of heterogeneous ethnographic material has already been collected and recorded, but a lot remains unrecorded and, gradually disappearing from life, being forgotten, dies forever for science" [5].

In his book, G.F. Chursin highlighted the most important features of customs, rites and views that surround, among the Caucasian peoples, certain sides and phenomena of folk life, as well as "separate pages from the great book of the history of human culture" [p. 23].

The population of Dagestan, according to historical information, has resorted to mutual labor assistance for a long time. For example, at pre-revolutionary times the highlanders of northern Dagestan asked for the help of neighbors during the harvest. This custom was called "vuka," which means "in bulk," "at once". The owner of "vuka" cooked millet ale, arrack (malt beverages), cut rams and announced in the village that tomorrow he would have "vuka." Young people who wanted to take part in it came the night before to declare their desire. The next day, from early morning, young people (sometimes up to 100 people) started to work noisily and cheerfully. They usually worked until noon; then they returned to the owner's house, where a feast took place, lasting until late in the evening. "The Avars in Dagestan," wrote G.F. Chursin, "resort to the help of neighbors and relatives in a number of works: such as, for example, fertilizing fields, shallow plowing and threshing corn, shearing sheep, washing and combing wool, claying saklia, throwing ground on their roofs, etc. This kind of labor assistance is called "goi" among the Avars. Relatives and neighbors invited to "goi" usually get a more or less luxurious treating, with vodka, millet ale, and sometimes Kalmyk tea" [5, p. 27]. N. Lvov wrote in detail about all this in the pre-revolutionary "Collection of Information on Caucasian highlanders." In the life of another nation of Dagestan (the Laks) the author saw more or less prosperous farms in need of outside help. During the summer field work, the owners invited familiar girls and young women for one or two days of work. This type of labor assistance was called "marsha." As G.F. Chursin wrote, "the owners do it precisely in such cases when bread ripened at once, and it needs to be removed as soon as possible, or when the haymaking place is far from the aul, and you need to mow it at once." [5, pp. 27-28].

The question of public assistance in some cases arose with special force. Under its pressure, a holy custom of mutual support was created. It was considered correct if "a peasant who for some reason did not have cattle, but who wanted to have it, invited his neighbors to dinner so that the invited would gift him a sheep or a cow at will (horses and 
bulls were usually not gifted). This custom was called "damazmukh" [5, p. 29]. At the same time, as always, observing the rules of the custom, the local highlanders resorted to providing real assistance to the devastated peasant when cattle died. This humanistic adat is observed in a number of regions of Dagestan at present.

It is known that the death of a family member causes material damage to the family. But the damage becomes significantly smaller if close relatives take part in the expenses associated with the funeral.

In Dagestan, it was also considered important to make the work of a farmer holy. The first furrow according to the local canons was to be conducted by the spiritual head of the village. At all times, the holidays of the "first furrow," "carrying the plow," "harnessing of bulls," etc. were organized in Dagestan.

In connection with the penetration of the Muslim religion into Dagestan (the 7th-16th centuries), the introduction of Islamic law into the life of the highlanders took place and, as a result, along with the adat court, the sharia court arose, which lasted until the mid-20s of the 20th century. For many centuries, there was a fierce struggle between two branches of judiciary, during which Sharia exerted all its efforts to destroy the adat court, but the latter, growing from the depths of history and recognized by the people, stubbornly resisted. Such outstanding historical figures as the first imams of Dagestan joined this struggle. However, convinced that it was impossible to destroy local adats, understandable and close to the people, the Muslim clergy set a course for peaceful coexistence with them, which undoubtedly affected the recognition of Sharia by the local population.

The reasons for the preservation of adats, both under the Islamists and after the coming of the Russians, were that they became a part of the self-consciousness and psychology of the highlanders, they reflected their understanding of the permissible and illegal, kind and evil, right and wrong, and therefore even Imam Shamil, despite his efforts, failed to replace customary law (adat) with religious law Sharia. After the capture of Imam Shamil in 1859 , adats again took their leading place in Dagestan society, although Sharia continued to operate along with them in the legal space.

The first adat court, which was allowed by the tsarist administration in Dagestan, was a court in the Samur district (village Ahty), which began to operate in 1839. In 1860, the powers of the adat courts were expanded, according to which the tsarist administration provided "people with a sentence that would fully correspond to their understanding and their customs and habits and allow gradually, without sharp transitions and damage to people, to move to sentencing according to Russian laws". At the same time, as necessary, it was decided to leave the proceedings on adat and Sharia in full.

According to Sharia the following cases were subject to consideration: disputes between spouses, parents and children, according to wills, controversial cases when it came to the mosque property, etc.

According to adat the following cases were subject to consideration: murder and blood revenge, wounds and mutilation, fights, courting another man's bride, bride kidnapping, as well as raping of women, debauchery, theft, robbery with the use of force, arson and damage of things, disputes about land between beks and peasants. According to the Russian military laws the following cases were subject to consideration: betrayal, rebellion, disobedience to representatives of authorities and murder of officials, theft of State property.

Cases were considered only when a complaint was received in a particular case and a certain respondent was identified. At the denunciation, the case was initiated only if the whole community suffered due to the case (for example, damage to bridges, roads, community land, etc.).

Great importance was attached to the oath of the plaintiff and his witnesses, the number of which reached from 1 to 40 people. Two types of oath were known: 1) in the name of Allah, according to Sharia; 2) the so-called khatuntallah or kebin-tallah ("if I give incorrect 
testimony, I promise to divorce my wife"). In the case of oath-breaking, the wife had to leave her husband and receive from him everything that belonged to her. At the same time, it must be emphasized that an oath was required when there was no way to find out the truth. Oath-breakers had never been allowed to oath again.

Let us turn to the characterization of the main traditions and customs that embodied the identity, national psychology and mentality of the highlanders.

The most noble tradition developed over many centuries and specially protected by the peoples of Dagestan is interethnic peace, friendship and cooperation between peoples, the desire to be always together in joy and in difficult situations, to defend the honor and dignity of their homeland together.

It should be emphasized that in the history of the Dagestan peoples there were also destructive invasions of uninvited Mongol-Tatar newcomers, Tamerlane and Nader Shah and others; political fragmentation and economic instability. However, at the same time, there was never a confrontation between one Dagestan people and another. History does not know a single case of struggle between them. And such a feature of the multinational region is not accidental.

According to linguists, historians, all Dagestan peoples have single deep historical roots. Since Early Bronze (i.e. about 6 millennia ago), there has been a single ethnic and cultural community on the territory of Dagestan (i.e. a single people with its own language, customs and traditions). The comparative historical study of the modern Dagestan languages and traditional culture leaves no doubt about their general root and origin, despite the numerous differences that arose in later times. And, nevertheless, even now linguists, and ordinary citizens who are fond of the problems of linguistics, find many common correspondences in the Dagestan languages, that once again confirms the conclusion that all the peoples of Dagestan have common roots.

History and ethnography indicate to the constant friendship of the Dagestan peoples, their continuous multilateral political, economic and cultural cooperation, development and accumulation of the whole system of mediation techniques, maslahat, tolerance, and resolution of disputes peacefully. That is why neither the strife of the Middle Ages nor the blood feud nor the invasion of uninvited guests nor other reasons could quarrel and divide the Dagestan nationalities.

At all times Dagestan has been and remains a unique and unified historical and cultural community, a real school of tolerance, worthy trade-offs, free functioning and development of 32 native languages and cultures, their versatile cooperation. Of all the oldest Dagestan traditions, the guests of the Country of Mountains are most attracted and amazed by the custom of hospitality, which indicates to human kindness and respect between people (even complete strangers). Apparently, this custom came from the distant antiquity, because, according to some guests, it is simply impossible to understand those ordinary highlanders who, seeing in the streets of their village a man who first found himself in a given aul and was lost, where he should go on the eve of the night, invite him to their house. The guest, thanks to the acquaintance with an unfamiliar but noble person, receives not only the shelter, but also warmth, food and a good bed.

The following proverbs are known in Dagestan: "Let such a day not come when a guest does not come to the house," "The guest is a messenger of Allah" and others. Thus, according to the customs of the peoples of Dagestan, each highlander should receive a guest with dignity whenever he comes day or night. In the mountains of Dagestan, the following custom has existed for centuries: when a family sits down to have lunch or dinner, all food is divided between family members and a portion is separated in case "a belated guest comes". If a person found himself in the aul for the first time and did not have his kunaks (friends), he usually went to the godecan (meeting place in the aul), where elderly wise people sat until late at night. After the welcoming Assalam Aleykum, the guest report- 
ed who he was, what his name was, from what district and what led him to the aul. Upon learning that the newcomer did not have kunaks in the aul, each of those sitting at the godecan offered him to stay with him. However, preference to accept the guest was given to the elder. If the traveler found himself in the aul at night, he could knock on the door of any house, say who he was and why he arrived, and the owners should have received him warmly. In the West Avaria, the traveler did not go to the godecan, but went into any house and said: "Let's be brothers." Such a guest was considered very honorable. The highlander considered it his high moral duty to receive the guest and provide him with attention and services. The inscription on the stone slab fixed on the house of the Highlander-Dido says about this: "Not out of pride or vanity, not for the sake of honors or pleasures, a real house was built, but in order to receive dear guests in it and give them a convenient rest after a difficult journey. Every guest entering this house will find an honor, complete security, conveniences and shelter." In all auls, the guest was assigned the best room (kunatskaya (a room for guests or friends), a living room). It was considered a shame if anyone insulted the guest. The owner of the house in such cases had to take revenge on the offender. By tradition, highlanders are more attentive to the person of another nationality, that found himself in the aul, realizing that such a person is more difficult in unusual conditions. The highlanders did not let the guest out of the house with empty saddlebags. They put bread, meat, cheese, some kind of gift into them. When the guest left, the owner usually accompanied him to the border of the aul, thereby demonstrating that he was under his protection.

People say: there is one step from hospitality to kunachestvo (friendship). Since ancient times, there has been a wonderful custom of kunachestvo in Dagestan, when the guest and the owner, by the will of circumstances, became close people, friends. They were ready to sacrifice their property and position in order to maintain and strengthen their friendship. Their relationship was sometimes so close that after the death of their parents, the kunak took the children of the deceased kunak into his family, raised and provided them with everything necessary on an equal basis with his children.

There are several types of kunachestvo in Dagestan. Kunak, inherited by the family from his grandfather, father, and older brothers, was considered traditional. These close and friendly relations were preserved forever and passed from generation to generation. In our auls, the most respected family was considered the one with many kunaks. Kunaks were together both on joyful and sad days, helped each other in the most difficult periods of life. They talked to kunak in his native language. Kunak and his children often learned each other's languages.

Some Dagestan peoples had the custom of atalychestvo (fosterage). Its name comes from the Turkic word "atalyk" which means fatherhood. According to this custom, children were given to the family of a relative from their tuhum (union of teips) or to the family of another tuhum, thereby consolidating the kinship of two tuhums. There were cases of giving children to the kunaks from other villages and even of other nationalities so that they would learn to speak other languages, master some kind of craft. Taking children families had to prove themselves as families with a high reputation, decent and good deeds. This custom was especially common among the Kumyks, the Nogais, residents of Derbent, the Didos, the Kaitags. Atalyk is a teacher, he had to take care of his foster child as of his native son. The child had to grow up healthy and hardworking, be able to ride a horse, own weapons, know the Koran, be brought up in a spirit of mountain ethics and decency.

One of the highest forms of friendship between people was the custom of twinning. As a rule, people who fell into a difficult, dangerous life situation and jointly adequately overcame it, became twins. After such trials, people became close friends, and the friendship that arose in this way subsequently grew into twinning. As you know, the twinning ceremony was performed either in the form of an oral oath on the Koran to be a faithful friend and a brother, or by mixing blood of both men. This was done as follows: both friends mixed 
drops of their blood from the incisions of their fingers in a drink (tea, water, etc.) poured into a bowl, and then drank it, which meant that they became blood brothers.

Peculiar rules of behavior, standards of morality, good manners have developed in Dagestan over the long centuries. They were based on a sense of self-esteem especially protected by the highlanders. The people of Dagestan believed that it was better to kill themselves than to blush in front of fellow countrymen, villagers, relatives for their dishonorable act and therefore tried to control themselves, preventing deviations from Jamaat (collective) instructions. All men were raised in this spirit, and, of course, they considered themselves superior to women, as evidenced by some nuance. A.A. Bestuzhev (Marlinsky), a famous Decembrist writer, who had been in exile in Derbent for four years (from 1830 to 1834), wrote the story Ammalat Bek, in which these "nuances" are clearly marked. Telling that young people gathered not far from the village Buinak for horse racing and trick riding, the writer gives a number of interesting facts that characterize local customs: "Women without covers, in colored headscarves curled up on their heads, in long silk shirts pulled together with short caftans (tunics) and in wide tumans (pantaloons) sat down in rows..." Explaining the word "tuman," the author notes: "Although, in fact, there is no difference between male shalvars (wide trousers) and female tumans (pantaloons), it will be a shame for a man if you say that he wears tumans, and vice versa." It would seem to be a trifle, but how vividly it highlights superfine borderlines of the moral positions of mountain men and women... And interestingly, in the daily life of the Dagestan people, we meet not only this, but also a lot of work performed exclusively by women (for example, going for water to the river, babysitting, cooking, baking bread, etc.) and exclusively by men (chopping firewood, tending cattle, soil digging, guarding the garden, etc.). "The restless fighting past of the mountain peoples of Dagestan," wrote G.F. Chursin, "created such a division of labor between male and female half of the population, in which most of the household responsibilities were attributed to women. The man, being primarily a warrior, took such works that could not be assigned to women." [5. p. 11]. At all times the inviolable rule in the mountains of Dagestan was the respect of the elders. "The old people are taken care of," G.F. Chursin noted, "they are freed from work, if possible, they are fed well, etc. Disrespectful and rude treatment towards the old is condemned by society." [5. p. 14].

The whole moral code of the highlanders hides behind the concept of "namus" (honor). Namus is most likely a complex of moral concepts admitted in the mountains, relating to men exclusively. Once it permeated all spheres of mountain life: honor, conscience, nobility, decency. The manifestation of namus arose there and then, when the male honor was assaulted.

However, the same namus contained many concepts of men`s arbitrariness, it contained wild ideas about honor and pride of a man. For example, when a wife left a husband it was considered a disgrace to the man, an insult to his honor. In many auls, it was considered impossible for a woman to act as a witness in the hearing of some case. The loss of namus was considered if the man (even with a sick wife) went for water to the river or to the spring. And there were many such inconsistencies that came to us from the past and testified to the former unequal position of the woman mountaineer. Sometimes echoes of such customs, unfortunately, are found in the modern life of the highlanders.

Residents of Dagestan were guided by the whole system of rules and ethical standards, observation of which was obligatory. For example, it was regulated how a highlander should build his life, how to greet a person, how to behave in public places, up to details, specific words, gestures, taking into account age, gender, occupied position. Everything was directed not to assault the honor and dignity of a man. Everywhere in Dagestan, men, when meeting each other, say the Muslim greeting "Assalam Aleykum" ("Peace to you"). At the same time, heartfelt wishes are used, which are probably nowhere in the world; for example, the Laks say: "May Allah give you that what you do not expect!" the Avars say 
"Bright day does not pass you!" the Akushintsy say "May you blossom like a garden!"

There are old rituals that every Dagestan must observe: for example, the first to greet must be the one who rides on horseback, the youngest greets the eldest, a man returning from the mountain greets a rising one, a passing man greets a sitting one, a coming man greets gathered people. In all auls, it was considered obligatory to come and greet the villager who returned from a distant trip. Leaving they say: "Wherever you go, may you return healthy" [10, p. 18].

A special place in the system of moral standards was occupied by the category of shame. Every highlander had to be careful both in deeds and in words when fulfilling generally recognized customs and standards of behavior. It was considered a shame: if a person committed a discreditable act; If adult children abandoned their parents and failed to take care of them; if a person betrayed his friends and loved ones; if a person borrowed money and do not give it back to the creditor; if a person stole something; if people drank, cursed and fought; if men, seeing how the weak were beaten, left or ran away; if a man, being cowardly, did not protect his wife, sister, mother, generally a woman from any attacks, etc.

According to the customs of the highlanders, if you came to the aul after a long separation, you needed to visit the houses in which the misfortune happened with two or three closest relatives. Leaving the visited people, the highlander says: "May all of you remain in health and well-being!" "May such bad events pass you by!," "May your health and joy remain!" Until the highlander makes a visit, neither the victim of the disaster nor his closest relatives will visit him, and they will consider themselves offended.

This is only a part of Dagestan customs and traditions, which largely reveal the essence of the original Dagestan mentality. In accordance with these customs and traditions more than one generation of worthy highlanders was brought up and grew up, showing their optimism, their vital capacity, their faith in the inviolability of mountain ethics, which is based on such remarkable qualities as modesty and courage, love for loved ones, for neighbors, for other peoples and the desire to improve themselves constantly and be a worthy son of the homeland.

\section{Лumepamypa}

1. Ахмедов Д.Н. Дагестан: вера, надежда, любовь. Махачкала: Юпитер, 2001.

2. Дирр А.М. Материалы для изучения языков и наречий андо-дидойской группы. Тифлис, 1909.

3. Казимбек А.К. Мюридизм и Шамиль // Русское слово. 1839. С. 182-242.

4. Камалова О.Н. Эстетическое освоение действительности в контексте философских идей Шеллинга // Гуманитарные и социально-экономические науки. 2008. № 1 (38). С. 67-69.

5. Ковалевский М.М. Народы Кавказа. СПб: типография М.И. Акинфиева, т.1. 1914.

6. Леонтович Ф.И. Адаты кавказских горцев // Материалы по обычному праву Северного и Восточного Кавказа. Одесса. Вып.1.1882; Вып.2. 1883.

7. Мустафраева М.Г., Мустафраев М.В. Вопросы социально-психологического поведения личности: национальные и этноконфессиональные аспекты // Известия Северо-Кавказского научного центра высшей школы. 1987. № 2. С. 95

8. Чурсин Г.Ф. Очерки по этнологии Кавказа. Тифлис, 1913.

9. Maida G. Mustafaeva, Elmira Sh. Musaeva, Zarema S. Mustafaeva. Various Problems of Educational Process in Multilingual Dagestan Under the Globalization Conditions: History and Modernity // Научный альманах стран Причерноморья. 2018. № 1 (13). C. 11-18. 
10. Sarat G. Hiyasova, Maida G. Mustafaeva, Elmira Sh. Musaeva. Religious traditions and beliefs in the culture of Dagestan: history and modernity // Научный альманах стран Причерноморья. 2020. Том 23. № 3. с. 95-101.

\section{References}

1. Akhmedov D.N. Dagestan: vera, nadezhda, liubov [Dagestan: faith, hope, love]. Makhachkala: Jupiter, 2001 (in Russian).

2. Dirr A.M. Materialy dlia izucheniia iazykov i narechii ando-didoiskoi gruppy [Materials for the study of languages and dialects of the Ando-Dido group]. Tiflis, 1909 (in Russian).

3. Kazimbek A.K. Miuridizm i Shamil. Russkoe slovo [Muridism and Shamil. Russian word]. 1839. pp. 182-242 (in Russian).

4. Kamalova O.N. Esteticheskoe osvoenie deistvitelnosti v kontekste filosofskikh idei Shellinga. Gumanitarnye i sotsialno-ekonomicheskie nauki [Aesthetic mastery of reality in the context of Schelling's philosophical ideas. Humanitarian and socio-economic sciences]. 2008. No. 1 (38). pp. 67-69 (in Russian).

5. Kovalevsky M.M. Narody Kavkaza [Peoples of the Caucasus]. Saint Petersburg: printing house of M.I. Akinfiev, V. 1. 1914 (in Russian).

6. Leontovich F.I. Adaty kavkazskikh gortsev. Materialy po obychnomu pravu Severnogo i Vostochnogo Kavkaza [Adats of Caucasian highlanders. Materials on customary law of the North and East Caucasus]. Odessa. Issue 1. 1882; Issue 2. 1883 (in Russian).

7. Mustafaeva M.G., Mustafaev M.V. Voprosy sotsialno-psikhologicheskogo povedeniia lichnosti: natsionalnye i etnokonfessionalnye aspekty. Izvestiia Severo-Kavkazskogo nauchnogo tsentra vysshei shkoly. [Issues of socio-psychological personality development: national and ethno-confessional aspects. News of the North Caucasus Scientific Center of Higher Education]. 1987. No. 2. 95 p. (in Russian).

8. Chursin G.F. Ocherki po etnologii Kavkaza [Essays on the ethnology of the Caucasus]. Tiflis, 1913 (in Russian).

9. Maida G. Mustafaeva, Elmira Sh. Musaeva, Zarema S. Mustafaeva. Various Problems of Educational Process in Multilingual Dagestan Under the Globalization Conditions: History and Modernity. Science almanac of Black Sea region countries. 2018. No. 1 (13). pp. 11-18.

10. Sarat G. Hiyasova, Maida G. Mustafaeva, Elmira Sh. Musaeva. Religious traditions and beliefs in the culture of Dagestan: history and modernity. Science almanac of Black Sea region countries. 2020. V. 23. No. 3. pp. 95-101. 